\title{
Of Different Complexions: Religious Diversity and National Identity in James II's Toleration Campaign
}

\section{Citation}

Sowerby, Scott. Of different complexions: Religious diversity and national identity in James II's toleration campaign. English Historical Review 124, no. 506: 29-52.

\section{Published Version}

http://dx.doi.org/10.1093/ehr/cen363

\section{Permanent link}

http://nrs.harvard.edu/urn-3:HUL.InstRepos:2897166

\section{Terms of Use}

This article was downloaded from Harvard University's DASH repository, and is made available under the terms and conditions applicable to Other Posted Material, as set forth at http:// nrs.harvard.edu/urn-3:HUL.InstRepos:dash.current.terms-of-use\#LAA

\section{Share Your Story}

The Harvard community has made this article openly available.

Please share how this access benefits you. Submit a story.

Accessibility 
This is an author-produced version of an article accepted for publication in The English Historical Review. The final version of this article will be available online in February 2009 at http://ehr.oxfordjournals.org.

\author{
Of Different Complexions: Religious Diversity and National Identity \\ in James II's Toleration Campaign* \\ by Scott Sowerby
}

One of the most remarkable speeches ever given by an English monarch was delivered by James II in the city of Chester on 27 August 1687. This speech deserves the attention of historians but has never been published, surviving only in a first-hand account written by a Cheshire gentleman in his diary. That diary has been held for the past eighty years in the municipal archives of Liverpool. ${ }^{1}$ Like many similar diaries, it largely consists of an unembellished record of the diarist's daily appointments as he called on his neighbours. An unusually long entry for 27 August 1687 was uncovered by the present author, buried among the briefer accounts of the diarist's social engagements. This entry has not been cited in any of the standard published works on James II's reign and has gone largely unnoticed, with the exception of a passing mention in an unpublished dissertation on the

\footnotetext{
*This article grew out of research I conducted while holding the Clive and Packard fellowships at Harvard University and a dissertation fellowship from the Social Sciences and Humanities Research Council of Canada. I owe thanks to those institutions and to several individuals. Ann Blair, Evan Haefeli, Mark Kishlansky, Noah McCormack, Monica Poole, Jonathan Scott, Owen Stanwood and the journal's two anonymous readers contributed valuable comments. The article has also benefited from the suggestions of those who heard versions of it read at the Northeast Conference on British Studies at Dalhousie University and the Early Modern History Workshop at Harvard University.

${ }^{1}$ Liverpool Record Office, 920 MD 172-5, Diary of Sir Willoughby Aston, 1681-1702 [hereafter Aston Diary]. Diary entries from March 1681 to February 1685 were serialised in Cheshire Sheaf, III, xxiv-v (1927-8), III, lvi (1961), III, lx (1965) and IV, i (1966).
} 
politics of Cheshire. ${ }^{2}$ The royal remarks recorded in the diary entry deserve greater attention than they have heretofore received as they provide insights into several aspects of English history, including the formation of national identity, the character of political rhetoric and perceptions of difference in skin colour.

Little attention has been paid to James II's electoral tour of the western counties of England in the summer of 1687, of which the visit to Chester was a part. His tour was designed to allay protestant suspicions of his motives as a catholic king and to encourage the election of Members of Parliament who would support religious toleration. ${ }^{3}$ It is possible that his speech at Chester was not unique and was simply his standard stump speech. There are hints in other sources that suggest this may have been the case. ${ }^{4}$ Whether or not the speech was unique, the newly uncovered diary entry is now the fullest extant account of what the king was saying on his tour. Although the account is highly mediated, being recorded by a gentleman in his diary at least two hours after the address was given, other comparable sources of the king's thoughts on politics are also heavily mediated. ${ }^{5}$ Very few letters and papers in James II's own hand survive from the period of his reign. His address at Chester provides the clearest evidence yet uncovered of what

\footnotetext{
${ }^{2}$ P.J. Challinor, 'The Structure of Politics in Cheshire, 1660-1715' (Wolverhampton Polytechnic Ph.D. thesis, 1983), 143.

${ }^{3}$ Archives des Affaires Etrangères [hereafter AAE], Paris, Correspondance Politique, Angleterre [hereafter CPA], clxii, fos. 169-v, Barrillon to Louis XIV, 10/20 Sept. 1687. The electoral tour has not been the focus of any sustained investigation, although it has been mentioned in most narrative histories of the king's reign. See, for instance, F.C. Turner, James II (London, 1948), 332-4; J.R. Western, Monarchy and Revolution: The English State in the 1680s (London, 1972), 209; J. Miller, James II: A Study in Kingship (London, 1978), 173; T. Harris, Revolution: The Great Crisis of the British Monarchy, 1685-1720 (London, 2006), 229-30.

${ }^{4}$ See below, footnote 43 .

${ }^{5}$ Many of the king's official declarations were drafted by his ministers, as is attested by National Library of Wales, Canon Trevor Owen MSS, nos. clvii-clx, and Bodleian Library, Don. c. 38, fo. 298, newsletter for 6 Oct. 1688 .
} 
he thought was the purpose of his electoral tour, who he hoped to persuade and what community he reckoned would respond to his rhetoric.

James II's wider efforts on behalf of toleration are well known and have been scrutinised by several generations of historians. Most historians have taken their cue from Thomas Babington Macaulay, who asserted that the April 1687 Declaration for Liberty of Conscience was 'unconstitutional' and that the king by issuing it had 'trespassed' on the right of Parliament to make laws. Some have questioned whether James's commitment to toleration was sincere and permanent, or whether it was merely temporary and tactical. The king, it is contended, did not show much sympathy for protestant nonconformists in his early years, and his campaign for a broad-based toleration can be seen as a ruse to obtain political cover for the toleration of Catholics. ${ }^{6}$ Other historians have argued for the king's sincerity, in part because of his continued promotion of toleration after his overthrow in the Revolution of 1688-9. ${ }^{7}$ The debate over the king's motives has tended to dominate any discussion of his reign.

Either side in this debate could claim the king's address at Chester as evidence for its position. The speech could be read as a document that shows the sincerity of James's commitment to religious toleration. Or it could be read as a document that shows the extent to which he was prepared to be devious. Neither reading is adequate. To read the

\footnotetext{
${ }^{6}$ T.B. Macaulay, The History of England from the Accession of James the Second, ed. C.H. Firth (6 vols., London, 1913-15), ii: 862; G.M. Trevelyan, The English Revolution (London, 1938), 63, 74-8; idem, England under the Stuarts (rev. edn., London, 1946), 356; Harris, Revolution, 166, 171, 235-6, 249-55; S. Pincus, 'The European Catholic Context of the Revolution of 1688-89: Gallicanism, Innocent XI and Catholic Opposition', in A.I. Macinnes and A.H. Williamson, eds., Shaping the Stuart World, 1603-1714: The Atlantic Connection (Leiden, 2006), 98-102.

${ }^{7}$ V. Buranelli, The King and the Quaker (Philadelphia, 1962), 13-16, 201-13; M. Ashley, 'Is There a Case for James II?' History Today, 13 (1963), 347-52; J. Miller, 'James II and Toleration', in E. Cruickshanks, ed., By Force or By Default? The Revolution of 1688-1689 (Edinburgh, 1989), 14-15; E. Corp, 'James II and Toleration: The Years in Exile at Saint-Germain-en-Laye', Royal Stuart Papers, no. 51 (Huntingdon, 1997), 4, 9.
} 
speech solely for the information it might divulge about the purity of the king's motives would be to underrate its importance. The address was a work of political rhetoric designed to persuade its audience. ${ }^{8}$ Whether sincere or devious in intent, its language illuminates larger questions about the nature of identity formation in early modern England. In his speech the king articulated a new form of collective belonging that was predicated on a novel understanding of English identity. He implicitly challenged the dominant mode of national identity formation in early modern England, one that was based on the primacy of Protestantism. ${ }^{9}$ By placing this speech in context, one can demonstrate that English national identity in the late seventeenth century was plural. Different Englishmen and women held different beliefs about what characteristics defined their nation. The Revolution of $1688-9$, moreover, which has been construed as a rising of the English nation in defense of English norms, can be reconceived as a contest between two English communities, each holding to a different sense of English national identity.

The immediate context of the king's speech can be summarised as follows. Several Whig leaders from Cheshire were introduced to the king. James exchanged greetings with them before addressing them. His address took the form of a staged dialogue. His interlocutor in this dialogue was Sir William Williams, the solicitor general, who had formerly been the Speaker of the House of Commons and a Whig Member of Parliament for Chester. The king explained his policy of religious toleration

\footnotetext{
${ }^{8}$ For an outline of the approach to political rhetoric being employed here, see Q. Skinner, Visions of Politics (3 vols., Cambridge, 2002), i: 175-87, ii: 344-67.

${ }^{9}$ On the relationship between Protestantism and English national identity, see P. Collinson, The Birthpangs of Protestant England (Basingstoke, 1988), 7, 10-11; T. Claydon and I. McBride, 'The Trials of the Chosen Peoples: Recent Interpretations of Protestantism and National Identity in Britain and Ireland', in T. Claydon and I. McBride, eds., Protestantism and National Identity: Britain and Ireland, c.1650-c.1850 (Cambridge, 1998), 26, 28-9.
} 
and urged his audience to support it. The solicitor general closed the event by suggesting that all those present should back pro-toleration candidates in the anticipated parliamentary elections.

The king's remarks at Chester are important enough to bear quoting at length. The diarist recording those remarks was Sir Willoughby Aston, a 47-year-old Cheshire baronet affiliated with the Whig group in local politics. ${ }^{10}$ Sir Willoughby had shown little enthusiasm for the king's religious policies and most likely opposed them. In his diary entry for 27 August 1687, he noted the following:

. . we went to the Miter, ${ }^{11}$ where Lord Brandon, Lord Delamere Sir Thomas Mainwaring, Sir Thomas Delves, Sir Robert Ducconfield Brother Offley etc. ${ }^{12}$ we went to Court $^{13}$ where Lord President Sunderland presented us to the King Lord Brandon telling our names. The King sayd he had not seen such an appearance of Gentry a great while, ${ }^{14}$ Lord Del[amere] told him we did not only appear there in Person but with our hearts and affections, or to that Effect. the King sayd he hoped so and our Countenances expressed no less, he told us he hoped we would join with him in endeavouring to set aside all animosities, and distinctions of parties and names, which would be done by removing the occasions, which were

\footnotetext{
${ }^{10}$ For Aston, see G. Ormerod, The History of the County Palatine and City of Chester (2nd edn., 3 vols., London, 1882), i: lxvii, 725-6.

${ }^{11}$ The Miter was a public house in Chester where Aston occasionally dined.

12 John Offley of Madeley, Aston's brother-in-law, had been held in the Tower of London along with Lord Delamere in 1685 under suspicion of treason.

${ }^{13}$ The reception was held at the Pentice, a civic building in Chester, where the king was 'seated under a canopy of crimson velvet, purposely prepared for him'. See Cheshire Record Office [hereafter CRO], Z/P/Cowper/1 (Historical Collections of William Cowper, vol. 1), 253; Ormerod, History of Chester, i: 248 .

${ }^{14}$ Earlier that day a large assembly of men including Aston, Lord Brandon and Lord Delamere had met the king on the county border to escort him to Chester.
} 
the Penall Laws and tests, ${ }^{15}$ and when he should think fit to call a Parliament, he hoped we would send him such men as would join with him in taking them away, that we might all agree and be easie. Williams made some reply that unity was better than Uniformity, and he hoped all would unite in being good subjects to his Majestie. the King sayd he had as soon as he could graunted [sic] a toleration, and hoped we would join with him in making a magna Charta for Conscience as well as properties and other liberties, he was sure no man should be debarr[e]d of either while he lived, ${ }^{16}$ suppose said he there should be a law made that all black men should be imprisoned, twould be unreasonable and we had as little reason to quarell [sic] with other men for being of different opinions as for being of different Complexions, desired we should shew our selfs Englishmen, and he was sure no Englishman could desire to see others persecuted for differences of opinion, and therefore again told us, the way to reconcile all differences was to take of[f] those Lawes which made men uneasie under them and deprived them of theyr Rights. to this Williams replyed as near as I can remember in these very words. Sir the indulgence is a probationary Law at present, and when your Majestie shall think fit to call a Parliament I doubt not but they will consider very

\footnotetext{
${ }^{15}$ The Elizabethan and Jacobean penal laws assessed various penalties and fines on those who absented themselves from Church of England services. The Test Act of 1673 required all holders of public office to take the sacrament according to the rites of the Church of England; the Test Act of 1678 required all Members of Parliament to make a declaration against transubstantiation.

${ }^{16}$ A note by Aston in the margin at this point gives another of the king's remarks: 'I may use that scripture expression whose Ox or whose Ass have I taken, and I hope you will Join in securing this liberty for the future'. The verse of scripture alluded to here is 1 Samuel 12:3, where the prophet Samuel asked the people of Israel 'whose ox have I taken? or whose ass have I taken?' With this remark James was claiming, like Samuel, to have respected his people's rights to their private property.
} 
well of it -- I went then with Sir Thomas Main[waring] and Sir John Corbet to Mr

Kenricks Hous[e] where they lay and thence home ... ${ }^{17}$

Bringing together elements from several political languages, the king argued for religious toleration on three separate grounds: that it was mandated by natural law, that it was an appropriate extension of the long-standing rights of Englishmen and that an Englishman who properly understood his own nature as an Englishman would support it. With these arguments, the king integrated different modes of discourse, including those of natural law and English constitutional law, to form a polyglot political language. ${ }^{18}$ Mark Goldie has recently observed that English political thought in the age of John Locke was marked by syntheses of contractarian natural jurisprudence and notions of a constitution said to derive from Saxon origins. ${ }^{19}$ Many politicians moved freely between these idioms, and James II was no exception.

Perhaps the most original of the king's three propositions was his argument from natural law. As Aston recorded it, the king said 'suppose . . . there should be a law made that all black men should be imprisoned, twould be unreasonable and we had as little reason to quarell [sic] with other men for being of different opinions as for being of different Complexions'. The king here made reference to a transcendent law of reason against which temporal laws could be tested and found reasonable or unreasonable. He

\footnotetext{
${ }^{17}$ Aston Diary, unpaginated, entry for 27 Aug. 1687. The original spelling, capitalisation and punctuation have been preserved in this transcript, but thorns have been modernised and standard abbreviations silently expanded. I would like to thank the Liverpool Record Office, Liverpool Libraries, for permission to publish this extract. For another, briefer account of the same occasion, see CRO, DDX 384/2 (Diary of Sir Thomas Mainwaring, vol. 2, 1674-88), 476, which states only: '[August] 27. That day I wa[i]ted on the king at chester, in the evening kissed his hand, and I did lye at Mr Kenricks all night.'

${ }^{18}$ On the structure of a 'political language', see J.G.A. Pocock, 'The Concept of a Language and the Métier d'Historien: Some Considerations on Practice', in A. Pagden, ed., The Languages of Political Theory in Early-Modern Europe (Cambridge, 1987), 19-38.

${ }^{19}$ M. Goldie, 'Introduction', in M. Goldie, ed., The Reception of Locke's Politics (6 vols., London, 1999), i: xxviii, xlv.
} 
challenged his audience to compare various statutes against this law of reason.

Specifically, he asked them to imagine a law that would require all black men to be imprisoned. Such a law would offend natural justice. He then suggested that a law restricting the freedom of men holding certain shades of opinion, here meaning religious opinion, was analogous to a law restricting the freedom of men possessing a certain shade to their complexions. If one was offensive to natural justice, the other was as well. The king's rhetoric relied upon his audience's agreeing with him that a law imprisoning all black men would be unreasonable.

In order for this chain of reasoning to bear the weight of the larger argument, the audience must have known what James meant by the 'complexion' of 'black men'. Skin tone or colouring was only one of several possible meanings of the word 'complexion' in early modern England. The word was also used in humoral theory to denote the underlying mixture of the four humours that prevailed in any given individual. Complexions, in this sense, could be described as sanguine, choleric, melancholy, or phlegmatic; but they were not usually described as 'black'. The term 'complexion' was also used in a looser sense to refer to a person's temperament. Blackness of complexion, then, might denote someone who was immoral or who had a faulty character. ${ }^{20}$ But this definition of 'complexion' does not fit the king's argument. If blackness of complexion were, for James, immorality of character, then in arguing for its toleration he would have been arguing for the toleration of wickedness. He would, moreover, have been equating religious nonconformity with immorality. Neither of these arguments would have advanced his case. It is more likely that the king was referring to skin tone when he

\footnotetext{
${ }^{20} \mathrm{R}$. Wheeler, The Complexion of Race: Categories of Difference in Eighteenth-Century British Culture (Philadelphia, 2000), 3.
} 
referred to 'complexions' and that his audience would have understood this to be his meaning. His general argument, then, would be that certain personal traits, including religious opinions and skin colour, were beyond punishment or blame and should be tolerated rather than quarreled with.

The hinge of the king's argument was the notion that the two personal characteristics of religious opinion and complexion were comparable. The nature of that comparison, though not stated explicitly in the text, can be inferred from the substance of the argument. The basis of the analogy would appear to be that both religious opinion and complexion were involuntary. Neither of these characteristics were chosen, and so the individuals who possessed them could not reasonably be punished or stigmatised for them, either through imprisonment by law or 'quarreling' by individuals.

By suggesting that religious opinions were involuntary the king had moved onto contentious terrain. This was terrain he had visited before. He asserted in his Declaration for Liberty of Conscience that persecution was ineffective and had proved incapable of inducing a uniformity of belief in the nation. Opponents of religious persecution often maintained that religious beliefs, or religious 'opinions' as they were sometimes called, could not readily be altered by methods of compulsion because no person could easily change them. Persecution, then, would induce at most a kind of hypocrisy where people were forced to make public statements that they did not truly believe. $^{21}$ Defenders of persecution conceded at times that belief itself was involuntary, but they argued that the pathway to belief was, nevertheless, chosen. The experience of persecution was effective in changing minds, they contended, in that it provided an

\footnotetext{
${ }^{21}$ James II, His Majesties Gracious Declaration to all his Loving Subjects for Liberty of Conscience (London, 1687, Wing J186), 2; Thomas Hobbes, Leviathan, ed. R. Tuck (Cambridge, 1991), 323.
} 
occasion for the persecuted to receive education and to contemplate whether their original beliefs had been true. ${ }^{22}$

It is surprising to find James arguing that religious opinions were involuntary given that he himself had changed his religion in the early 1670 s by joining the Church of Rome. He seems to have convinced himself that his early life as a Protestant was merely a period of rote obedience to a faith he neither internalized nor understood. Thus by converting he had not chosen to trade one belief for another; instead, he had exchanged an unexamined habit for a true belief. ${ }^{23}$ He may also have felt that his conversion had been involuntary, that it had been compelled by unimpeachable logic or by the power of God and thus he had not chosen it of his own free will. He once described himself as having become a Catholic despite all its political disadvantages because 'being fully convinced he could resist no longer'. ${ }^{24}$ This was a common argument in the seventeenth century: Thomas Hobbes argued that religious belief is 'not voluntary' because it can only be altered by 'the power of God'. James appears to have believed that he was incapable of returning to the protestant faith even if he wanted to: he had become convinced by Catholicism and that conviction was now fixed unalterably in his mind. ${ }^{25}$

\footnotetext{
${ }^{22}$ This position was put forward by St Augustine in his comments on Luke 14:23, 'Go out into the highways and hedges, and compel them to come in'; Augustine's comments remained influential in seventeenth-century England. See M. Goldie, 'The Theory of Religious Intolerance in Restoration England', in O.P. Grell, J. Israel and N. Tyacke, eds., From Persecution to Toleration: The Glorious Revolution in England (Oxford, 1991), 334-8; J. Marshall, John Locke, Toleration and Early Enlightenment Culture (Cambridge, 2006), 201-206.

${ }^{23}$ See James II's letter to his daughter Mary in Mechtild, gräfin von Bentinck, ed., Lettres et Mémoires de Marie Reine d'Angleterre (The Hague, 1880), 4.

${ }^{24}$ J.S. Clarke, The Life of James the Second (2 vols., London, 1816), i: 631; see also the similar accounts in Bentinck, Lettres et Mémoires, 6; Gilbert Burnet, Bishop Burnet's History of His Own Time (2nd edn., 6 vols., Oxford, 1833), i: 305; idem, A Supplement to Burnet's History of My Own Time, ed. H.C. Foxcroft (Oxford, 1902), 52.

${ }^{25}$ Hobbes, Leviathan, 323; Campana de Cavelli, Les Derniers Stuarts à Saint-Germain en Laye (2 vols., Paris, 1871), i: 285.
} 
The tolerationist line of reasoning about the involuntary character of religious belief led to analogies that anticipated in form, if not entirely in content, the comparison made by James. Sir William Temple wrote in 1673 that:

Belief is no more in a man's power, than his Stature or his Feature; And he that tells me, I must change my Opinion for his, because 'tis the truer and the better, without other Arguments, that have to me the force of conviction, May as well tell me, I must change my gray eyes for others like his that are black $\ldots{ }^{26}$

John Locke in his Letter Concerning Toleration, composed in the winter of 1685, wrote that laws penalising forms of religious belief were as egregious as laws that made distinctions 'between men and men, upon account of their different Complexions, Shapes, and Features, so that those who have black Hair (for example) or gray Eyes, should not enjoy the same Privileges as other Citizens' ${ }^{27}$ James's analogy was similar in form to Temple's and Locke's, breaking new ground in that it referred to 'black men' rather than men with black hair or black eyes.

It is unclear whether in referring to 'black men' James meant Africans or whether he meant Englishmen of a dark and swarthy complexion. Either meaning was possible in contemporary usage. One common expression held that swarthy men and fair women preferred each other, as in Shakespeare's Two Gentlemen of Verona where Proteus notes that 'Black men are pearls in beauteous ladies' eyes'. Similarly Hugh Holland wrote that ‘in faire womens eyes | Blacke men seeme pearles', while Margaret Cavendish had it that

\footnotetext{
${ }^{26}$ Sir William Temple, Observations upon the United Provinces of the Netherlands (London, 1673, Wing T656), 168. Note the use of 'Opinion' as a synonym for 'Belief', as was typical at the time. I would like to thank Jonathan Scott for this reference.

${ }^{27}$ John Locke, A Letter Concerning Toleration (London, 1689, Wing L2747), 50-1; for the date of writing, see Marshall, John Locke, 690. James's remarks at Chester cannot have been influenced by Locke's Letter as it was not published until 1689. For another analogy of this sort, see London Gazette, no. 2294 (10-14 Nov. 1687).
} 
'the Usual Saying was, that Black men Liked and Loved Fair women best' ${ }^{28}$ Aside from this saying, however, Europeans with dark complexions were rarely described collectively as ‘black men' in early modern England while Africans were often described collectively as 'black men'. ${ }^{29}$ The complexion of Africans was, moreover, frequently employed as a symbol of immutability in the early modern period. One saying used by dramatists was the proverb that 'to undertake to wash a Black, [is to] Labour in vain.'30 Versions of this proverb can be found in the plays of John Webster, Thomas Dekker and John Fletcher and in the works of John Bunyan, who wrote in Pilgrim's Progress that 'they saw one Fool, and one Want-Wit, washing of an Ethiopian with intention to make him white, but the more they washed him, the blacker he was. ${ }^{31}$ A London pub called 'The Labor in Vayne' issued trade tokens in the mid-seventeenth century depicting two women washing a black man. ${ }^{32}$ The proverb had its origins in classical and Biblical

\footnotetext{
${ }^{28}$ William Shakespeare, Two Gentlemen of Verona, 5.2.12; Hugh Holland, Pancharis: The First Booke (London, 1603, STC 13592), lines 1005-6; Margaret Cavendish, CCXI Sociable Letters (London, 1664, Wing N872), 211. See also M.P. Tilley, A Dictionary of the Proverbs in England in the Sixteenth and Seventeenth Centuries (Ann Arbor, 1950), 408; R.W. Dent, Proverbial Language in English Drama Exclusive of Shakespeare, 1495-1616 (Berkeley, 1984), 496.

${ }^{29}$ For the description of Africans as 'black' in the early modern period, see W.D. Jordan, White Over Black: American Attitudes Toward the Negro, 1550-1812 (Chapel Hill, 1968), 11-20; J. Walvin, Black and White: The Negro and English Society, 1555-1945 (London, 1973), 19-21; M. Floyd-Wilson, English Ethnicity and Race in Early Modern Drama (Cambridge, 2003), 78-86. References to black Africans as 'black men' are too numerous to cite in their entirety. They include Richard Hakluyt, The Principal Navigations (3 vols., London, 1599-1600, STC 12626a), iii: 52; Peter Heylyn, Mikrokosmos (Oxford, 1625, STC 13277), 778; and Samuel Purchas, Purchas his Pilgrimes (4 vols., London, 1625, STC 20509), i: 120 (first pagination), i: 42 (second pagination), ii: 960, iv: 1148.

${ }^{30}$ Giovanni Torriano, The Second Alphabet Consisting of Proverbial Phrases (London, 1662, Wing T1930), 91; see also John Ray, A Collection of English Proverbs (London, 1670, Wing R386), 164; F.P. Wilson, ed., The Oxford Dictionary of English Proverbs (3rd edn., Oxford, 1970), 868; Tilley, Dictionary of the Proverbs, 190; Dent, Proverbial Language, 320.

${ }^{31}$ John Bunyan, The Pilgrim's Progress from this World to that which is to Come: The Second Part (London, 1684, Wing B5576), 186; John Webster, The White Devil, 5.3.270-1; Thomas Dekker, The Honest Whore, Part II, 1.1.89; idem., The Roaring Girl, 1.2.185-6; John Fletcher, The Woman's Prize, 3.3.11; idem., The False One, 1.2.56.

${ }^{32}$ The name was presumably meant to suggest that competing pubs would 'labour in vain' to produce better brew. A London chandler and a London brewer issued tokens with similar devices. See W. Boyne, Trade Tokens Issued in the Seventeenth Century, rev. G.C. Williamson (2 vols., London, 1889-91), i: xix, 606,
} 
tropes, as in the prophet Jeremiah's rhetorical question 'Can the Ethiopian change his skin, or the leopard his spots? ${ }^{33}$

At the same time other tropes circulating in early modern England suggested that complexions were changeable. The notion of an indelible blackness of complexion might be parodied, as when Queen Anne and her attendants were painted black in the first performance of Ben Jonson's Masque of Blackness in 1605 and her husband King James was accorded the power to turn them white. Jonson, inverting the usual proverb, wrote that the king was like a sun whose enlightening beams were able 'To blanch an Ethiop'. ${ }^{34}$ Early modern natural philosophers queried whether skin colour was fixed by heredity or whether it could be altered by exposure to sunlight. Some argued that complexions could change permanently under the influence of climate. ${ }^{35}$ James might have been aware of these arguments that skin colour was mutable under certain climatic conditions. If he meant to invoke these claims, the analogy he was drawing would have been rendered even more apt. Religious belief, then, would be like skin tone in that it was both involuntary and mutable; any alterations that occurred in one's complexion were, like alterations of religious belief, a result not of conscious choice but of the influence of God or the influence of the climate in which one lived.

690-1, 781; S.C. Chew, The Crescent and the Rose: Islam and England during the Renaissance (New York, 1937), 523-4.

${ }^{33}$ Jeremiah 13:23, in the King James Version. On the development of this proverb from the classical to the early modern period, see C. Prager, "If I be Devil": English Renaissance Response to the Proverbial and Ecumenical Ethiopian', Journal of Medieval and Renaissance Studies, xvii (1987), 257-79; J.M. Massing, 'From Greek Proverb to Soap Advert: Washing the Ethiopian', Journal of the Warburg and Courtauld Institutes, lviii (1995), 180-201.

${ }^{34}$ Ben Jonson: The Complete Masques, ed. S. Orgel (New Haven, 1969), 56.

${ }^{35}$ Francis Bacon, Sylva Sylvarum (London, 1627, STC 1168), 105-6; K.F. Hall, Things of Darkness: Economies of Race and Gender in Early Modern England (Ithaca, 1995), 95-6; J.E. Chaplin, 'Race', in D. Armitage and M.J. Braddick, eds., The British Atlantic World, 1500-1800 (Basingstoke, 2002), $162,166$. 
With his analogy James enunciated a principle of colour-blind justice, contending that it would be unreasonable to quarrel with a man because of his complexion or to imprison a 'black' man because of the tone of his skin. This would be so whether the king meant to refer to Africans or to swarthy Englishmen when he spoke of 'black men'; in either case he was arguing against a form of discrimination based on skin colour. But even if he meant to refer to Africans, he was not necessarily making an abolitionist statement. He did not refer explicitly to slavery in his speech, referring instead to the possibility of 'imprisonment'. He had, moreover, shown no abolitionist leanings in his private business dealings. As Governor of the Royal African Company for the quarter century after its foundation in 1672, he presided over the expansion of English involvement in the Atlantic slave trade. He was the single largest shareholder in the Royal African Company and he possessed a North African slave in the 1670s. These activities were a source of personal profit for James and they do not appear to have troubled his conscience. ${ }^{36}$

Little is known, however, of the king's understanding of slavery. It is possible that some element in his thinking would allow him to make a categorical statement against colour-based prejudice without repudiating his activities in support of slavery. He may, for instance, have believed that black men and women were being enslaved as individuals rather than as a class and that their skin colour was not the reason for their enslaved status. One line of argument at the time held that African slaves had been

\footnotetext{
${ }^{36}$ James had also been the governor of the Company of Royal Adventurers into Africa that preceded the formation of the Royal African Company. See K.G. Davies, The Royal African Company (London, 1957), 41, 59, 65, 71, 74, 103; Walvin, Black and White, 38-9; E.M.G. Routh, Tangier, England's Lost Atlantic Outpost, 1661-1684 (London, 1912), 168-9; Tangier at High Tide: The Journal of John Luke, 1670-1673, ed. H.A. Kaufman and P. Kaufman (Geneva and Paris, 1958), 53; The Diary of John Evelyn, ed. E.S. de Beer (6 vols., Oxford, 1955), iv: 471.
} 
captured by their enemies in just wars on the African continent and thus, according to a particular reading of international law, had forfeited their freedom. John Locke advanced this idea in his Second Treatise on Government when he defined slavery as 'the State of War continued, between a lawful Conqueror, and a Captive'. ${ }^{37}$ Some historians have contended that the early transatlantic slave trade was conducted without much reference to skin colour and that racism was only later developed as a justification for the continued enslavement of Africans in the eighteenth century. If James believed that his slavetrading activities were not directed against black men in general, he could invoke a colour-blind principle of justice at Chester without self-contradiction. His remarks could then be taken as corroborating the argument made by some historians that the early transatlantic slave trade, as practiced by some Englishmen, was not predicated on a racial hierarchy in which men and women with darker complexions were seen as candidates for enslavement principally because of the colour of their skin. ${ }^{38}$

The king's speech was remarkable in its use of two novel analogies. One analogy compared a law penalising religious nonconformity and a law penalising black men. James thus associated the laws he was seeking to overturn with a variety of prejudice that he assumed his audience would reject. The other compared his project for toleration and

\footnotetext{
${ }^{37}$ John Locke, Two Treatises of Government, ed. P. Laslett (Cambridge, 1960), 302; see also Jordan, White Over Black, 68-9.

${ }^{38}$ For this argument, see G.M. Fredrickson, 'Toward a Social Interpretation of the Development of American Racism', in N.I. Huggins, M. Kilson, and D.M. Fox, eds., Key Issues in the Afro-American Experience (2 vols., New York, 1971), i: 242-8; E.S. Morgan, American Slavery, American Freedom: The Ordeal of Colonial Virginia (New York, 1975), 325-31; Wheeler, Complexion of Race, 46, 58, 91-2, 100 , 128-9. For the counter-argument that the early slave trade was a product of racism, see Jordan, White Over Black, 80, 89-98; C.N. Degler, 'Slavery and the Genesis of American Race Prejudice', Comparative Studies in Society and History, ii (1959), 52, 62, 66; P.D. Morgan, 'British Encounters with Africans and African-Americans, circa 1600-1780', in B. Bailyn and P.D. Morgan, eds., Strangers Within the Realm: Cultural Margins of the First British Empire (Chapel Hill, 1991), 212-13.
} 
the Magna Carta signed by King John in 1215. James thus associated the ideas he was seeking to promote with a revered document that he knew his audience would value. With these two analogies he depicted his toleration project as representing the best impulses of his audience and not the worst. This was inventive rhetoric, and it is surprising to find it voiced by a monarch who has not gone down in history as a Cicero or a Demosthenes. $^{39}$

With his second analogy the king drew together the distinct political languages of constitutionalism and contractarian jurisprudence, thereby putting the language of the ancient constitution to a new purpose: his Magna Carta would effectively be a new social contract. ${ }^{40}$ As Aston wrote, the king said that he 'hoped we would join with him in making a magna Charta for Conscience as well as properties and other liberties, he was sure no man should be debarr[e]d of either while he lived'. The analogy itself was inexact for the Magna Carta of 1215 had been imposed on King John by a baronial revolt, while King James was pressing his own charter on a somewhat diffident nation.

Nevertheless, James gained a rhetorical advantage by cloaking his proposals in language that indicated his fealty to the original Magna Carta. He presented his project not as something that was radically new but as something that would extend liberties that had long been enjoyed, not as a set of mandates but as a movement for reform that he hoped his subjects would join. The tone of the address at Chester was more beseeching than commanding. If Aston's recollection was correct, the king did not order his subjects to follow him; he 'hoped', rather, that they would 'join with' him. This was conciliatory

\footnotetext{
${ }^{39}$ For one account of James's limitations, see Turner, James II, 234-6.

${ }^{40}$ On the language of the 'ancient constitution' in early modern England, see J.G.A. Pocock, The Ancient Constitution and the Feudal Law (Cambridge, 1957); J. Greenberg, The Radical Face of the Ancient Constitution: St. Edward's 'Laws' in Early Modern Political Thought (Cambridge, 2001).
} 
rhetoric with a defensive purpose. His opponents had alleged that his proposals would unsettle the titles to the abbey lands confiscated by Henry VIII, thereby allowing the Church of Rome to wrest them from their current owners. Such a result would violate the property rights guaranteed by the Magna Carta. The king was aware of these allegations; to counter them he co-opted the language of constitutionalism for his own campaign. ${ }^{41}$

James did not argue at Chester that religious toleration was a right guaranteed by the ancient constitution of England; indeed, he implicitly conceded that the constitution as it currently stood did not encompass any such right. His rhetorical strategy was to elevate liberty of conscience to the status of a right that ought to be guaranteed in the same way as private property. He reinforced this point later in his speech when he asserted that 'the way to reconcile all differences was to take of[f] those Lawes which made men uneasie under them and deprived them of theyr Rights.' The concept of 'rights' was, like the Magna Carta, an idea that bridged natural jurisprudence and constitutional law. Those rights could be taken to be the rights of men as secured by natural law or, alternatively, the rights of Englishmen as secured by their constitution. It is possible that the king was referring to both senses of the word with deliberate ambiguity. Whichever meaning he intended, his use of the term 'rights' was a clear statement of the conception of liberty that Isaiah Berlin was later to term 'negative' liberty: the notion of a freedom from the coercive power of other human beings. ${ }^{42}$ The

\footnotetext{
${ }^{41}$ Gilbert Burnet, Six Papers (n.p., 1687, Wing B5912), 22; James II, Declaration for Liberty of Conscience, 4. For the king's commissioning of a tract to demonstrate that the tenure of the abbey lands was securely fixed in their current holders, see West Yorkshire Archive Service, Leeds, MX/R, 48/35, Nathaniel Johnston to Sir John Reresby, 7 April 1687; idem., MX/R, 48/25, same to same, 23 June 1687; Nathaniel Johnston, The Assurance of Abby and other Church-Lands (London, 1687, Wing J872).

${ }^{42}$ I. Berlin, Two Concepts of Liberty (Oxford, 1958), 6-7; see also B. Bailyn, The Ideological Origins of the American Revolution (Cambridge, Mass., 1967), 77-8; Q. Skinner, 'The Idea of Negative Liberty: Philosophical and Historical Perspectives', in R. Rorty, J.B. Schneewind and Q. Skinner, eds., Philosophy in History (Cambridge, 1984), 193-221.
} 
king conceived of the 'lawes' as a burden that made his subjects 'uneasie'; his toleration project would ease that burden by taking off the statutes that 'deprived' his people of their 'rights'. In this conception of liberty, statutes enforced by governments were instruments of coercion that could deprive individuals of rights guaranteed by a transcendent natural law. In the particular instance to which the king was referring, the statutes that oppressed the English people were the penal laws and Test Acts while the right being violated was their right to liberty of conscience.

The proposed Magna Carta for liberty of conscience was a touchstone of James II's rhetoric in 1687 and 1688 . He spoke of it on at least ten separate occasions. ${ }^{43}$ His first known use of the expression came in April 1687, four months before his remarks at Chester, when he informed a group of Presbyterians that he 'heartily wished there was A Magna Charta for Liberty of Conscience as well as for their Properties' ${ }^{44}$ Earlier in that same month, a similar expression had appeared in a tract that advocated 'another Great Charter, to bury all our Prejudices, and Establish a lasting Civil union among the Inhabitants of this Ancient and Famous Kingdom.' This tract has been attributed to

\footnotetext{
${ }^{43}$ Longleat House, Thynne MSS, xv, fo. 199, Sir Robert Southwell to Lord Weymouth, 29 Aug. 1687; CRO, D/MH/1 (Matthew Henry's Chapel Book, 1687-1923), fo. 7v; West Yorkshire Archive Service, Leeds, MX/R, 51/50, Leonard Wilson to Sir John Reresby, 7 Jan. 1688; The Entring Book of Roger Morrice, ed. M. Goldie, J. Spurr, T. Harris, S. Taylor, M. Knights and J. McElligott (6 vols., Woodbridge, 2007), iv: 185; Matthew Henry, The Life of the Rev. Philip Henry, ed. J.B. Williams (London, 1825), 181; M.G. Hall, ed., 'The Autobiography of Increase Mather', Proceedings of the American Antiquarian Society, 1xxi (1961), 325; Burnet, History of His Own Time, iii: 162, 190; W.A. Speck, Reluctant Revolutionaries: Englishmen and the Revolution of 1688 (Oxford, 1988), 67 n.51; The Humble Address of the Presbyterians (n.p., 1687, Wing A2912), 8. For the date of the address to which the king was responding in this last instance, see London Gazette, no. 2248 (2-6 June 1687).

${ }^{44}$ Folger Shakespeare Library, Newdigate newsletters, L.c.1803, 28 April 1687; Entring Book of Roger Morrice, iv: 39; for the Presbyterian address that the king was responding to, see London Gazette, no. 2238 (28 April-2 May 1687).
} 
William Penn. ${ }^{45}$ It is possible that the king picked up his new expression in conversation with Penn, the Quaker tolerationist and founder of Pennsylvania who was his close confidant. He was known to listen carefully to what Penn had to say; when asked once why he spent time with the Quaker, he replied that Penn 'talk'd Ingeniously' and that he 'heard him willingly'. 46

William Penn was an intellectual architect of the king's toleration project and one of its leading exponents. ${ }^{47}$ The Quaker had long been a champion of constitutional reform, both in his frame of government for Pennsylvania and in his political writings. As he wrote in 1675, 'England's Circumstances are greatly changed, and they require new Expedients' ${ }^{48}$ The key reform would be religious toleration which would secure the property rights of nonconformists, thereby increasing the nation's industriousness while reducing the anger that fueled opposition movements. ${ }^{49}$ Penn argued that the confiscation of goods and money from dissenters constituted a violation of their rights to

\footnotetext{
${ }^{45}$ A Second Letter from a Gentleman in the Country (London, 1687, Wing P1361), 18, dated 11 April 1687 on the title page; M.M. Dunn and R.S. Dunn, eds., The Papers of William Penn (5 vols., Philadelphia, 1981-7), v: 337 n.1, 341.

${ }^{46}$ Gerard Croese, The General History of the Quakers (London, 1696, Wing C6965), book 2, p. 106. For Penn's presence at court at about this time, see Library of the Religious Society of Friends, London [hereafter LSF], A. R. Barclay MSS, no. cxi, Robert Sandilands to John Field, 22 June 1687; Entring Book of Roger Morrice, iv: 73. For the earlier development of Penn's friendship with James, see American Philosophical Society, Philadelphia, William Penn papers, 974.8 P365, vol. i, pp. 115-16, printed in William Penn, 'Fragments of an Apology for Himself', Memoirs of the Historical Society of Pennsylvania, iii, 2 (1836), 241-2.

${ }^{47}$ M.K. Geiter, William Penn (Harlow, 2000), 49-51, 54-8.

${ }^{48}$ William Penn, England's Present Interest Discover'd (London, 1675, Wing P1280), 39.

${ }^{49}$ Ibid., 40-4, 46-7; William Penn, The Great Question to be Considered by the King, and this Approaching Parliament (n.p., 1679, Wing P1300), 6; idem., A Perswasive to Moderation to Dissenting Christians (London, 1685, Wing P1337A), 25-6, 30, 33-4. Penn repeated this argument in his Advice to Freeholders and Other Electors of Members to Serve in Parliament (London, 1687, Wing P1250), 4-5, and his Third Letter from a Gentleman in the Country (London, 1687, Wing P1381), 6.
} 
private property as guaranteed by the Magna Carta. ${ }^{50}$ From this claim it was a short step to his subsequent argument that the laws of England should guarantee liberty of conscience as well as property rights. As early as 1679 he had described a proposed new law securing religious liberty as a kind of 'Magna Charta'. ${ }^{51}$

This phrase was picked up again by Penn and his friend James in $1687 .^{52}$ The Quaker drew large crowds to his speeches that year, in part because he was seen as a public spokesman for the crown. He defended the king's Declaration for Liberty of Conscience before an audience of three thousand in Bristol, a sizeable crowd given that the city's population was no more than twenty-five thousand. ${ }^{53}$ He spoke to large, religiously diverse crowds on a tour across England in the summer of $1687 .{ }^{54} \mathrm{He}$ accompanied James on his electoral tour and gave speeches along the route. He was willing to speak uninvited in marketplaces even when that attracted hostile attention, as at Shrewsbury where the citizenry cried him down. ${ }^{55}$ At Chester he held forth in a local

\footnotetext{
${ }^{50}$ Penn, England's Present Interest, 37, 45, 61; idem., Perswasive to Moderation, 20-1; idem., The Great Case of Liberty of Conscience (n.p., 1670, Wing P1299), 29.

${ }^{51}$ Penn, Great Question to be Considered, 8; see also his Great Case of Liberty, 21.

${ }^{52}$ William Penn, Good Advice to the Church of England, Roman Catholick, and Protestant Dissenter (London, 1687, Wing P1296), 45; idem., The Great and Popular Objection against the Repeal of the Penal Laws \& Tests Briefly Stated and Consider'd (London, 1688, Wing P1298A), 6, 8, 10, 22.

${ }^{53}$ Marquis of Lansdowne, ed., The Petty-Southwell Correspondence, 1676-1687 (London, 1928), 279; John Whiting, Persecution Expos'd, in some Memoirs Relating to the Sufferings of John Whiting (London, 1715), 172; G. Cope, 'Letter from William Hitchcock to John and Amy Harding, 1687', Journal of the Friends Historical Society, iv (1907), 73; J. Latimer, The Annals of Bristol in the Eighteenth Century (Frome and London, 1893), 6, 194.

${ }^{54}$ Penn visited Chew Magna, Devizes, Marlborough, Newbury, Reading and Windsor, addressing crowds numbering in the hundreds or more. See LSF, A. R. Barclay MSS, no. cxi, Robert Sandilands to John Field, 22 June 1687; Whiting, Persecution, 172-3; Cope, 'William Hitchcock', 73, 75.

55 Shropshire Archives, Leighton MSS, 180/1, printed in Historical Manuscripts Commission, The Manuscripts of the Earl of Westmorland, Captain Stewart, Lord Stafford, Lord Muncaster, and Others (London, 1885), 376.
} 
theatre where 'above a thousand people' came to hear him defend liberty of conscience. ${ }^{56}$ Although attendance at a meeting does not necessarily entail support for a political agenda, the large crowds drawn by the Quaker leader suggest a certain amount of popular enthusiasm for the tolerationist policies he was advocating.

By the end of the year Penn's idea of a new Magna Carta for liberty of conscience had been widely popularised. ${ }^{57}$ In the eyes of many the new charter would be a new form of collective belonging. Pamphlets published by the king's followers developed the contractarian logic inherent in the idea. One author proposed the institution of a 'new test' whereby every adult male in the kingdom would swear annually to 'observe and keep Unviolable' the 'new Magna Charta' for liberty of conscience. These oaths would be sworn on the king's birthday. In a nod to Penn, the author made an exception for Quakers and others who were unable to swear an oath; they would be permitted to make an affirmation instead. ${ }^{58}$ One Whig journalist in the king's pay wrote in September 1687 that liberty of conscience was everyone's concern, not just the concern of a few: 'For if it be not General, it cannot be Effectual; But by a General Security equally including All Parties, the Fears and Jealousies of Each must vanish'. To institute this general security,

\footnotetext{
${ }^{56}$ Papers of William Penn, iii: 163; Aston Diary, entry for 28 Aug. 1687; AAE, Paris, CPA, clxii, fos. 169v-170, Barrillon to Louis XIV, 10/20 Sept. 1687; LSF, Temp MSS, 285, no. xlii (Notebook of Robert Barclay), p. 42; The Diary of Dr. Thomas Cartwright, Bishop of Chester, Camden Society, old series, xxii (London, 1843), 74; 'The Theatre in Foregate Street, Chester', Cheshire Sheaf, III, xliv (1949), 43.

${ }^{57}$ See London Gazette, nos. 2288 (20-24 Oct. 1687), 2295 (14-17 Nov. 1687), 2325 (27 Feb.-1 March 1688), 2327 (5-8 March 1688), 2329 (12-15 March 1688), 2351 (28-31 May 1688); A Collection of the Newest and Most Ingenious Poems (London, 1689, Wing C5205), iii. For critiques of Penn's proposal, see Some Queries Concerning Liberty of Conscience, Directed to William Penn and Henry Care (n.p., [1688], Wing S4559), 1, 3-4; Thomas Comber, Three Considerations Proposed to Mr. William Pen[n], Concerning the Validity and Security of his New Magna Charta for Liberty of Conscience (n.p., [1688], Wing C5496), $1-2$.

${ }^{58}$ Giles Shute, A New Test in Lieu of the Old One (London, 1687, Wing S3710), 1, 10. For Shute's printer, the Baptist George Larkin, who was in receipt of royal funding, see J.Y. Akerman, ed., Moneys Received and Paid for Secret Services of Charles II and James II, Camden Society, old series, lii (London, 1851), 213.
} 
the king and Parliament should enact a new law declaring that 'Liberty of Conscience is part of the Constitution of this Kingdom', and that anyone who endeavored 'to undermine or subvert such [a] Settlement, shall be adjudg'd Criminal, and liable to such Penalties as shall be thought fit' ${ }^{59}$ These proposals were similar in certain respects to the social contract outlined by Thomas Hobbes in his Leviathan thirty years earlier. The idea of a general security underpinned by the consent of every citizen had been advanced by Hobbes when he proposed a 'Covenant of every man with every man' that would remove the fears and insecurities occasioned by life in the state of nature. The proposal to impose penalties on those who broke the new social contract was reflected in Hobbes's dictum that after the formation of a commonwealth 'he that dissented must now consent with the rest ... or else justly be destroyed by the rest. ${ }^{, 60}$ If these Hobbesian methods had been followed, the establishment of liberty of conscience would paradoxically have ushered in a new era of persecution. Punishments would have been meted out on political rather than religious grounds, but this would have been persecution nonetheless, as those who refused to subscribe to the new social contract came under penalty.

The king made appeals at Chester both to natural law and to the rights of Englishmen in urging the establishment of a permanent liberty of conscience. To these he added an appeal to his audience's sense of national pride. According to Aston, the king said that he 'desired we should shew our selfs Englishmen, and he was sure no Englishman could

\footnotetext{
${ }^{59}$ Henry Care, Animadversions on a Late Paper Entituled, A Letter to a Dissenter (London, 1687, Wing C505), 17, 37; Akerman, Secret Services, 199; Folger Shakespeare Library, Newdigate newsletters, L.c.1862, 27 Sept. 1687. William Penn made a similar argument in his Third Letter from a Gentleman, 1819, as did William Popple in his Three Letters Tending to Demonstrate (London, 1688, Wing P1382A), 1516. For Popple's authorship of this pamphlet, see Caroline Robbins, 'Absolute Liberty: The Life and Thought of William Popple, 1638-1708', William and Mary Quarterly, III, xxiv (1967), 190 n.1.

${ }^{60}$ Hobbes, Leviathan, 120, 123.
} 
desire to see others persecuted for differences of opinion'. With this statement, the king elevated national identity above other forms of collective identity in England. He was responding to a situation in which his subjects had divided into competing groups, the 'animosities and distinctions of parties and names' that he alluded to earlier in his address. By referring to 'animosities' the king hinted at the divisions that had caused conformists to persecute nonconformists. The 'distinctions of parties and names' had been sharpened by the Whig and Tory parties that came into being over the previous decade. The king at Chester steered his subjects away from thinking of themselves primarily as Whigs or conformists, Tories or nonconformists, and toward thinking of themselves first and foremost as English. In modern times political scientists have posited that inter-group tensions in a diverse society can be reduced if political leaders articulate an overarching identity that encompasses all members of that society. ${ }^{61}$ This was the strategy that James II pursued in 1687.

To execute this strategy, the king needed to advance a definition of English identity that was broad enough to encompass all English citizens. The dominant concept of national identity in post-Reformation England did not suit this end, for it was based on the primacy of Protestantism and the stigmatisation of Catholics. The king omitted any mention of Protestantism in his address at Chester. He substituted liberty of conscience as the bedrock principle of English identity. To be English was, therefore, to be tolerant. Most English Catholics had come to accept the necessity of toleration and could be

\footnotetext{
${ }^{61}$ N.G. Jesse and K.P. Williams, Identity and Institutions: Conflict Reduction in Divided Societies (Albany, 2005), 3, 8-12; R.D. Putnam, 'E Pluribus Unum: Diversity and Community in the Twenty-first Century', Scandinavian Political Studies, xxx (2007), 161-5.
} 
subsumed under this overarching definition of national identity. ${ }^{62}$ The new definition was non-sectarian in nature. By calling on his subjects to show themselves to be 'Englishmen' and by defining Englishness as essentially tolerant, the king was suggesting that national identity should trump other forms of collective identity, including religious affiliation.

A similar idea was expressed by Sir William Williams, the solicitor general, in his introduction to the king's speech. According to Aston's diary the Welsh lawyer stated that 'unity was better than Uniformity, and he hoped all would unite in being good subjects to his Majestie.' As part of an introduction to an address on toleration, the word 'uniformity' had a religious connotation, evoking the 1662 Act of Uniformity that expelled most Presbyterian ministers from the Church of England. Williams thus suggested that although the religious composition of the nation was not uniform the nation could remain united under the crown, with the king serving as the centripetal force holding it together. The effect of his suggestion was to elide differences between Protestants and Catholics, subsuming them within an overarching unity that was grounded on political principle. This was the effect of the king's speech as well.

James articulated at Chester a version of English national identity that diverged sharply from the dominant version in post-Reformation England. If the exact nature of that divergence remains somewhat elusive and difficult to describe, it is in part because of the poverty of the analytical vocabulary presently available to describe it. The standard typology developed by political scientists for distinguishing between various

\footnotetext{
${ }^{62}$ London Gazette, nos. 2246 (26-30 May 1687), 2260 (14-18 July 1687), 2350 (24-28 May 1688); Clarke, James the Second, ii: 115; W.K. Jordan, The Development of Religious Toleration in England (4 vols., Cambridge, Mass., 1932-40), iv: 437-65; J.D. Krugler, English and Catholic: The Lords Baltimore in the Seventeenth Century (Baltimore, 2004), 6-7, 247; A.J. Brown, 'Anglo-Irish Gallicanism, c. 1635-c. 1685' (Univ. of Cambridge Ph.D. thesis, 2004), 24-8, 85-8, 131-2, 137-47.
} 
forms of national identity is of limited use when applied to the early modern period.

Students of modern nationalism often compare nations that adopt a 'civic' identity based on voluntary adherence to laws and constitutions with those that adopt an 'ethnic' or 'ethnocultural' identity based on blood ties or inherited cultural affiliations. This binary distinction found its classic statement in comparisons of modern France with modern Germany. In this view post-revolutionary France possessed a 'civic' mode of national identity formation, adhering to a tradition of republican constitutionalism, while nineteenth-century Germany possessed an 'ethnic' mode of identity formation, privileging blood relations among citizens as the basis for unification and nationhood. ${ }^{63}$ This typology, once used to describe differences between nations, now tends to be used to describe differences within nations. Tensions can arise when sub-national groups form different ideas of the nation. One historian, for instance, has argued that nineteenthcentury France saw a divide between the 'civic' nationalism that emerged from the Revolution of 1789 and a resurgent 'ethnic or cultural' nationalism based on Catholicism and rural folk culture. ${ }^{64}$

\footnotetext{
${ }^{63}$ H. Kohn, The Idea of Nationalism (New York, 1944), 329-31; M. Ignatieff, Blood and Belonging: Journeys into the New Nationalism (New York, 1994), 6-7; D. Brown, Contemporary Nationalism: Civic, Ethnocultural and Multicultural Politics (London, 2000), 51-58; A.W. Marx, Faith in Nation: Exclusionary Origins of Nationalism (Oxford, 2003), 113-17, 133, 141. For critiques of this distinction, see W. Kymlicka, 'Misunderstanding Nationalism', Dissent (Winter 1995), 131-3; D. Schnapper, 'Beyond the Opposition: "Civic” Nation versus "Ethnic” Nation', ASEN Bulletin, xii (1996-7), 4-8; T. Baycroft and M. Hewitson, 'Introduction: What was a Nation in Nineteenth-Century Europe?' in T. Baycroft and M. Hewitson, eds., What is a Nation? Europe 1789-1914 (Oxford, 2006), 7-8. These critiques point out that modern nations said to possess a civic form of nationalism invariably retain an ethnic, linguistic or cultural component in their dominant form of national identity. For a response to this line of criticism which seeks to rescue the distinction between civic and ethnic nationalism by conceiving it as a distinction between two ideal types, neither of which is ever fully realised in practice, see A.D. Smith, 'Civic and Ethnic Nationalism Revisited: Analysis and Ideology', ASEN Bulletin, xii (1996-7), 9-11.

${ }^{64}$ T. Baycroft, 'France: Ethnicity and the Revolutionary Tradition', in T. Baycroft and M. Hewitson, eds., What is a Nation? Europe 1789-1914 (Oxford, 2006), 32-4.
} 
These interpretive vocabularies are less useful for describing the societies of early modern Europe, where forms of national identity were typically grounded on religion. The idea advanced by some historians that forms of national identity based on religion are somehow 'ethnic' or 'ethnocultural' is difficult to sustain, as it relies on the premise that religious belief is largely involuntary and inherited. ${ }^{65}$ This premise runs counter to the self-understandings of many early modern men and women. The seventeenth century in Europe was a period of transition, not yet full of Enlightenment certainty that religious belief was involuntary and hence ought to be tolerated. Pre-Enlightenment thought often assigned religious belief to the category of voluntary action, while Enlightenment thinkers usually assigned religious belief to the category of involuntary action. ${ }^{66}$ If religious beliefs were voluntary, they could be adopted just as one might adopt a set of political beliefs or pledge allegiance to a national constitution. A form of national identity based on religion could thus be construed as 'civic' in nature. The divisions mapped out by the 'civic' versus 'ethnocultural' typology are themselves contested, constructed and historically variable.

Early modern political thinkers often agreed that citizenship ought to be based on the possession of voluntary characteristics rather than involuntary ones. This was a feature of the classical heritage as transmitted by the humanists: true citizenship was seen not as an inherited trait but as a form of virtue that could be pursued and perfected. ${ }^{67}$ In

\footnotetext{
${ }^{65}$ For this usage, see Marx, Faith in Nation, 115-7, 141; C. Williams, 'The United Kingdom: British Nationalisms during the Long Nineteenth Century', in T. Baycroft and M. Hewitson, eds., What is a Nation? Europe 1789-1914 (Oxford, 2006), 274, 283.

${ }^{66}$ Goldie, 'Religious Intolerance', 331-68; J. Kilcullen, Sincerity and Truth: Essays on Arnauld, Bayle, and Toleration (Oxford, 1988), 140-2.

${ }^{67}$ Q. Skinner, Visions of Politics, ii: 169-173; J.G.A. Pocock, The Machiavellian Moment: Florentine Political Thought and the Atlantic Republican Tradition (Princeton, 1975), 49-80.
} 
many early modern political debates the pivotal issue was whether a particular attribute required for full citizenship was in fact a voluntary characteristic. The agenda of James II's speech at Chester was precisely to intimate that religious belief is involuntary, that it ought be tolerated for that reason and that Englishness should not be based on an involuntary characteristic such as a particular form of religious belief. The speech thus formed a potent challenge to the way in which English national identity had been constructed over the previous century, a construction based on a form of religious belief that was widely believed to be a matter of voluntary choice. The king appears to have expected that his subjects would sympathize with these arguments. Yet his efforts failed with the Revolution of 1688-9, which became in part a counter-revolution against his revolutionary proposals. The efforts by the king to unify his nation behind a new version of English national identity had an unintended and disastrous consequence: they divided the nation between different groups espousing different ideals, thereby heightening the existing divisions within the English polity in the later seventeenth century.

The common thread in James II's rhetoric at Chester was an appeal to some higher principle — be it the ancient constitution, natural law or English identity—by which liberty of conscience could be seen as normative and the penal laws as unwarranted. The divergent languages of the king's remarks came together in the idea of a new Magna Carta for liberty of conscience. With this idea the king appropriated the language of the ancient constitution and used it to authorise his tolerationist agenda. The new charter would be the touchstone of English identity, reflecting the innate tolerance, in James's view, of the English people. It would subsume within it the divisions between 
competing political and religious groups that had been engendered by the Reformation and deepened by the Civil Wars. It would be a new social contract that would serve as the guarantor of the people's rights by overriding temporal laws that deprived them of those rights. The king had good reason to use the phrase 'a Magna Charta for Conscience' as often as he did. As a slogan it served to synthesise his arguments and had the added benefit of undercutting suspicion of his motives by countering any insinuations that English liberties were not safe under his rule.

Whether the king's rhetoric would resonate with an unsympathetic audience was not certain. His arguments were exhortative, not demonstrative. They could be deflected by anyone who wished to assert that Englishness was not, in fact, based on toleration but was based on the primacy of the protestant faith as established by law. Sir Willoughby Aston was just such a man. His attitude to nonconformity was captured in a catchphrase of his: 'either Popery would bring in Presbytery, or Presbytery, would bring in Popery'. His antagonism to both Presbyterianism and Catholicism stemmed from his fear that either, if left unchecked, would destroy his own Church. He believed that 'the Church of England was the only bulwark' against both and he 'wish'd it strong enough' to hold. ${ }^{68}$ His attitude towards the king's toleration campaign was indicated by his willingness to circulate a libellous poem about Sir William Williams after the solicitor general visited Chester. The poem lampooned Williams as a 'poor Wretch' whose 'lame submission' to the king had left him 'bankrupt in Hon[o]r'. ${ }^{69}$ Across the country, the Whigs split in reaction to the king's campaign, with some supporting it and others opposing it. Among

\footnotetext{
${ }^{68}$ Aston Diary, entry for 31 March 1685.

${ }^{69}$ CRO, CR63/2/691/39, Sir Willoughby Aston to Sir John Crewe, 23 Feb. 1688; for a variant copy of this poem, see Bodleian Library, MS Firth c. 15, 228-9.
} 
the Whig grandees present at the Chester speech, Brandon supported the project while Delamere opposed it. ${ }^{70}$ Aston had long been associated with the latter's party in local politics, although he did not join Delamere in his cavalry ride across England in November 1688 in support of the Dutch invasion..$^{71}$

As a hostile witness, Sir Willoughby had little incentive to make the king look good by embellishing his words. He might not have chosen to record the speech at all were it not so unusual for him to meet a sitting monarch. His first opportunity to write down the king's remarks would have been at least two hours after the speech, when he returned home later that evening. ${ }^{72}$ He himself claimed that his account was reliable, at least with reference to Sir William Williams's last comment, which he aimed to set down 'as near as I can remember in these very words'. Aston employed the device of direct quotation only with reference to this last phrase and to another phrase of the king's that he wrote in the margin of his diary; elsewhere he gave the dialogue in the third person as part of his retelling of what had happened. Such casualness was appropriate for a diary entry intended more as an aide-mémoire than a transcript for others to read. This casual relation unfortunately had the effect of obscuring the original phrasing. It is unclear whether the king originally stated that 'we should show ourselves Englishmen' or that

\footnotetext{
${ }^{70}$ M. Goldie, 'John Locke's Circle and James II', Historical Journal, xxxv (1992), 558-9; idem., 'James II and the Dissenters' Revenge: The Commission of Enquiry of 1688', Historical Research, lxvi (1993), 53-5. On Brandon, see Historical Manuscripts Commission, The Manuscripts of Lord Kenyon (London, 1894), 212-13, 234-5; Calendar of State Papers, Domestic Series, James II (3 vols., London, 1960-72), iii: 43. On Delamere, see D.H. Hosford, Nottingham, Nobles, and the North: Aspects of the Revolution of 1688 (Hamden, Conn., 1976), 38, 85-95.

${ }^{71}$ Aston Diary, entries for 25 Feb. 1685, 18 Nov. 1688.

${ }^{72}$ Aston was in the habit of writing up his diary on a daily basis at his home, Aston Hall, which was twelve miles northeast of Chester, about two hours journey by horseback. Occasionally, when away from home for a long stretch of time, he would keep a journal on a separate sheet of paper and then transcribe it into his diary later, specifying that he had done so; see his entries for 20 April 1683 and 6 April 1684. His trip to Chester on 27 August 1687 did not involve an overnight stay and it is evident from his reference to his journey home that he did not write up his diary until after his return.
} 
'you should show yourselves Englishmen', whether he employed the more humble first person plural or the more peremptory second person plural.

The extent of Aston's influence on the surviving text might be gauged by comparing the Chester address with other speeches that the king gave in 1687. Such comparisons are hindered by the paucity of the surviving evidence and the fact that other accounts were also taken down by diarists or scribes who may have skewed them in different ways. Direct and unmediated sources of the king's thoughts in this period are rare. His letters are few, and their brevity suggests that the king, unlike his grandfather and namesake, was not a man of the pen. The surviving sources tend to indicate that Aston's relation of the king's address was accurate in its substance. The king's statement at Chester that he had granted toleration 'as soon as he could' was paralleled in another speech in which he suggested that the reason nonconformists 'had this Liberty no sooner' was because of the objections raised by some Protestants. ${ }^{73}$ The king's reference at Chester to 'a magna Charta for Conscience as well as properties and other liberties' was paralleled by his statement to a group of Presbyterians that 'you shall as well have Magna Charta for the Liberty of Conscience, as you have had for your Properties.' The king also funded a sizeable propaganda campaign that echoed the themes he struck at Chester. ${ }^{74}$ He had some success in building a political movement that embraced his proposals, including the new charter for toleration that he and Penn advocated.

\footnotetext{
${ }^{73}$ Bodleian Library, Rawlinson MS D 924, fo. 391; see also the variant copy in Coventry Archives, BA/L/A/2/3. For the objections raised at court in 1685 to liberty of conscience, see J. Miller, Popery and Politics in England, 1660-1688 (Cambridge, 1973), 203.

${ }^{74}$ Humble Address of the Presbyterians, 8; G. Duckett, ed., Penal Laws and Test Act (2 vols., London, 1882-3), i: 195-6; Akerman, Secret Services, 196-7, 199, 213; J.R. Jones, The Revolution of 1688 in England (London, 1972), 105, 109-11, 116.
} 
At Chester, as on other occasions in 1687 and 1688, the king sought to reorient concepts of value that had long been held by Englishmen and women, elevating toleration as a virtue and omitting Protestantism as a defining characteristic of national belonging. ${ }^{75}$ The king's movement for reform was opposed by a counter-movement that sought to reaffirm the centrality of Protestantism to English nationhood. When the United Provinces invaded England in November 1688, the leader of the invading forces, Prince William of Orange, drew on the language of this counter-movement to present himself as the defender of English liberties against a catholic threat. ${ }^{76}$ The English Revolution of $1688-9$ was propelled by a rejection of the king's ambitious proposals for reform. In that sense it was a counter-revolution.

The form of national identity espoused by the king's opponents was the more dominant one in early modern England, but its hegemony was incomplete. To borrow a phrase from a historian writing in a different context, 'Nationalism is an attribute not of nations, but of nationalists. ${ }^{77}$ Ideas of national character could and often did vary from person to person. Not all early modern English men and women placed an opposition to the catholic 'other' at the center of their vision of Englishness. Some, including many Quakers and Catholics, understood their English identity as an attribute defined by loyalty to a monarch or to a set of moral practices rather than to a particular brand of

\footnotetext{
${ }^{75}$ For a theoretical discussion of the kind of society-wide shift in evaluative concepts that James II sought to precipitate, see Skinner, Visions of Politics, i: 178-81.

${ }^{76}$ The Declaration of His Highnes[s] William Henry, By the Grace of God Prince of Orange (The Hague, 1688, Wing W2328C), 1.

${ }^{77}$ D. Fitzpatrick, 'The Geography of Irish Nationalism, 1910-1921', in C.H.E. Philpin, ed., Nationalism and Popular Protest in Ireland (Cambridge, 1987), 403.
} 
Christianity. ${ }^{78}$ Historians of James II's reign have overlooked this clash of national identities because of an unwarranted assumption that a single nation possesses only a single form of national identity at any given moment in time. ${ }^{79}$

The supporters of the king's measures sought to present themselves as a mass movement. They composed addresses of thanks to the king after his Declaration for Liberty of Conscience was issued. These addresses were in some cases signed by hundreds or even thousands of hands. More than two hundred addresses from various groups and regions were sent to the king. ${ }^{80}$ Some were sweeping statements of tolerationist sentiment while others offered only tepid support. One common theme of the addresses was that the king had 'united' the nation under the standard of liberty. The situation that had prevailed before the king's declaration was described in terms reminiscent of Hobbes's state of nature. It was a state of affairs that had 'made one neighbour to be more like a Turk than a Christian to another' and had subjected nonconformists to 'continual Fears' of persecution and deprivation. The new state of affairs, by contrast, had caused a 'supernatural Union of all English Hearts'. The king's declaration had led to a state of peace like the one that had prevailed on Noah's ark: 'as in the miraculous preservation of Government in the Ark, even Creatures of most contrary Principles live together in the quiet and peaceable enjoyment of themselves'. This conciliatory effect was attributed to the king himself and to the principle of unified

\footnotetext{
${ }^{78}$ See J.E. Pomfret, 'Robert Barclay and James II: Barclay's “Vindication,” 1689', Bulletin of Friends Historical Association, xlii (1953), 36-7, 39.

${ }^{79}$ See for instance S. Pincus, “To Protect English Liberties”: The English Nationalist Revolution of 16881689', in T. Claydon and I. McBride, eds., Protestantism and National Identity: Britain and Ireland, c.1650-c.1850 (Cambridge, 1998), 78-80, 85, 92, 103-4.

${ }^{80}$ For copies of the addresses, see London Gazette for 1687 and 1688 . In most cases the names and numbers of the signatories have not survived, but see G.D.L., 'MSS. Written or Possessed by Ralph Thoresby, F.R.S.', Publications of the Thoresby Society, xxviii (1923-7), 442-3; Entring Book of Roger Morrice, iv: 42; Diary of John Evelyn, iv: 553-4; London Gazette, no. 2252 (16-20 June 1687).
} 
sovereignty, for without a monarch to provide peace 'we are apt to have such Feuds, Animosities, and Violence one against another, for every difference in Judgment and Practice, that we should be a miserable People'. It was the monarch who, like a harpist, had 'made an Harmony for Your Selfe and People, in the different Sounds from divers Strings, by the gentle touch of Your most skil[1]ful Hand'. The king, as 'the Common Father of Your Country' and the giver of liberty of conscience, could ensure that the 'interest of Parties are laid aside, [and] the Common Interest, Trade and Safety of the Nation, may be advanced and promoted by all ${ }^{81}$ Most of the addresses conspicuously failed to refer to Protestantism as a source of national unity and strength; instead, the foundations of national unity were said to be liberty of conscience and the monarchy. This praise of the monarch went beyond the sort of innocuous boilerplate that would be expected in any address of thanks to a king. The underlying thesis of the addresses was that an adept sovereign could take a rattled nation out of its state of disarray and bring it into a state of civil society.

Anyone who opposed the king's designs, one loyal journalist wrote, 'either do[e]'s not truly understand his Interest, or is no True-English-man'. ${ }^{82}$ A journalist from the opposite camp contended that, on the contrary, true patriotism was found in a readiness to resist the king's designs: 'I consider my self as an Englishman as well as a Protestant; and whatever I conceive may directly or by consequence prejudice my

\footnotetext{
${ }^{81}$ Address from Chichester, in London Gazette, no. 2270 (18-22 Aug. 1687); from Sussex nonconformists, in idem., no. 2297 (21-24 Nov. 1687); from the grand jury at Rochester, in idem., no. 2374 (16-20 Aug. 1688); from Berwick upon Tweed town council, in idem., no. 2359 (25-28 June 1688); from Norwich congregationalists, in idem., no. 2242 (12-16 May 1687); from Essex nonconformists, in idem., no. 2258 (7-11 July 1687); from Taunton weavers, in idem., no. 2284 (6-10 Oct. 1687).

${ }^{82}$ An Expedient for Peace: Perswading an Agreement amongst Christians (London, 1688, Wing E3872aA), 40. Similar passages are found in Henry Care, The Legality of the Court Held by His Majesties Ecclesiastical Commissioners (London, 1688, Wing C527), 31, 33.
} 
Religion, or Civil Rights, I think my self obliged not to consent to it, as I am to answer it to GOD and my COUNTRY.' One unhappy critic alleged that the king's employment of Catholics in high office was akin to allowing Turks and Muslims to run the government; either policy would lead to 'the Destruction of the Kingdom'. Another critic attacked the toleration of catholic 'idolatry', arguing that it would undermine the nation's very identity: 'The Laws and Constitution of a Country do denominate that Country; if Atheism were here Authorized by Law, this would be an Atheistical Nation; and if Idolatry be set up by Law, it is an Idolatrous Nation'. An observer of this feud commented on the adoption of 'the Air of a Patriott' in the published critiques of the king's policies. ${ }^{83}$ Varying ideals of patriotism helped to fuel the animosities between the king's supporters and his opponents.

The collective behaviour of some Anglicans was characterized by intolerance of religious dissent. In the summer of 1688 a group of butchers marched through the streets of London, clashing their cleavers against steel and crying out, 'No Declaration No Toleration No Baxter No Pen No Lob'. 'Baxter' was Richard Baxter the Presbyterian; 'Pen’ was William Penn the Quaker; 'Lob' was Stephen Lobb the Congregationalist. The latter two were known allies of the king. In December of 1688 a Quaker meetinghouse was put to the flames in Sunderland by local rioters during the time of disorder after the collapse of James II's government. ${ }^{84}$ That same month James, unnerved by defections within his army in the face of the advancing Dutch troops, departed England. Some

\footnotetext{
${ }^{83}$ Thomas Brown, Heraclitus Ridens Redivivus (Oxford, 1688, Wing B5060), 8; Some Queries, 2; Samuel Johnson, A Letter from a Freeholder (n.p., [1688], Wing J834), 5; Folger Shakespeare Library, V.a.469, William Westby, 'A Continuation of my Memoiers [sic]', fo. 34.

${ }^{84}$ British Library, Sloane MS 3929, fo. 69v, newsletter for 7 July 1688; Joseph Besse, A Collection of the Sufferings of the People Called Quakers (2 vols., London, 1753), i: 189-90.
} 
observers took his flight to France as a sign that his allegiance to England was weak; others saw the opposite in his persistent efforts to regain his throne. The French ambassador D'Avaux wrote in 1689 that the king had 'a heart too English to undertake anything that could vex the English'. This statement echoed one made by James to Parliament in 1685: 'I have a True English Heart, as Jealous of the Honour of the Nation as You can be ${ }^{85}$ The king's own body had become the grounds on which competing versions of English national identity were played out.

In seeking to accord full rights of citizenship to religious nonconformists, King James, a Catholic himself, advocated a new and more incorporative form of collective belonging. The king maintained that certain traits, including religious belief and physical complexion, were not an acceptable basis for punishment by the state or quarreling by individuals. He suggested that national laws and constitutions should be grounded not on mandating the uniform possession of involuntary characteristics, but rather on accommodating differences in those characteristics. Unity was not uniformity, and neither complexion nor religious opinion should be used as grounds for stigmatising others. This conception of Englishness tended towards a 'civic' or political identity in that it was founded on a common, willed adherence to a political creed or constitutionthe 'Magna Carta' for liberty of conscience. The new test of civic virtue would be adherence to this new 'Magna Carta', rather than to a particular religious creed. ${ }^{86}$

\footnotetext{
${ }^{85}$ Anchitell Grey, Debates of the House of Commons, from the Year 1667 to the Year 1694 (10 vols., London, 1763), ix: 17, 21; Négociations de M. le Comte d'Avaux en Irlande, 1689-90 (Dublin, 1934), 255: 'un coeur trop Anglois pour se determiner à rien qui puisse chagriner les Anglois'; S. Sowerby, 'Tories in the Whig Corner: Daniel Fleming's Journal of the 1685 Parliament', Parliamentary History, xxiv (2005), 182.

${ }^{86}$ For complaints about this 'new test' as a form of reverse discrimination, see $A$ Letter to a Dissenter from his Friend at The Hague (The Hague, 1688, Wing L1633), 3; Ten Seasonable Queries (n.p., [1688], Wing T674); Brown, Heraclitus, 5.
} 
At Chester and elsewhere during his toleration campaign, James II adopted a rights-based rhetoric of citizenship that had not previously been used by any English monarch. It is likely that he borrowed much of this rhetoric from William Penn, yet it is remarkable, given his reputation as an authoritarian, that he used it at all. This rhetoric gained a popular purchase among some of those who had been stigmatised by the laws that the king was seeking to overturn. His inclusive version of English national identity was overwhelmed nonetheless by a counter-attack that proved more effective than anything he could muster. Despite his inventive rhetoric and his funding of a broad propaganda campaign, his power to reshape the ideas of his people had been shown to be limited. King James had attempted to stretch a concept of national identity that proved ultimately to be inelastic.

Harvard University

SCOTT SOWERBY 